\title{
nature
}

\section{Where next on strategic arms?}

\section{The nuclear powers should start worrying about next year's review conference of the Non-Proliferation Treaty. The other members will expect much of them.}

THE nuclear powers will be in a serious jam this time next year. Then, they will no longer be able to put at the backs of their minds the knowledge that the third review conference of the NonProliferation Treaty (NPT) will be just a few months ahead. They will instead be haunted by bad memories of how the last conference broke up in August 1980 with the non-nuclear signatories of the treaty hurling recriminations at the Soviet Union, the United Kingdom and the United States (China and France do not even belong) for their failure to make progress towards the control of strategic arms. Heaven forbid another rough-house will be the cry a year from now. But in reality, in 1980 the nuclear powers had quite a lot to say. Since the previous conference in 1975, they had negotiated agreements to restrict the use of nuclear weapons for peaceful purposes and, more important, the complex of agreements known collectively as Salt II which restrict the numbers of strategic weapons the Soviet Union and the United States may deploy. True, neither agreement had been ratified by the governments concerned in 1980 (and neither has been even now), but surely, it must have seemed safe to argue, the fact that the agreements have been signed must be evidence of "good faith", the spirit in which NPT requires the superpowers to negotiate? In the event, that argument cut no ice. The nuclear powers were sent away with as clear a warning as they could have had that NPT could collapse if nothing happened on the control of strategic nuclear weapons. So, this time next year, the nuclear powers will be woefully aware that in 1985 they will have even less to say than in 1980 .

What has gone wrong? The Reagan Administration was slow to square its electoral rhetoric with its treaty obligations to negotiate on strategic arms, but eventually two parallel sets of talks were begun in 1982, on European missiles and on strategic missiles, both at Geneva. The first set of talks (called INF for Intermediate Nuclear Forces) broke down last November, when the Soviet delegates walked out of the Geneva negotiations in protest at the deployment of cruise and Pershing II missiles in Western Europe. Against expectations, the strategic talks (called START for Strategic Arms Reduction Talks) ran their planned course, but $\mathrm{Mr}$ Konstantin Chernenko, the new Soviet leader, keeps saying (most recently last weekend) that the talks are now suspended until cruise and Pershing missiles are removed from Europe. Since the impasse that has arisen will certainly persist until after the November election in the United States, but since both the nuclear superpowers want NPT to survive, there is a chance that this time next year they will have a common cause in putting together some tale they can tell the other members.

\section{Solutions}

What can they say or, better, do? Each will wish to persuade the non-nuclear NPT members that the other is to blame. That temptation should be resisted not only because mass defections from NPT will be no more tolerable if one or the other is thought to be responsible but also because the apportionment of blame conceals an important stumbling block to agreement on both INF and START. Long before the collapse of INF, the Soviet Union had argued that the British and French nuclear forces should be counted in the European balance of forces.

The point has some force. While the British and French Governments have built their nuclear forces for reasons which are to them strategic - ultimately to provide an element of deterrence against threats to national survival - the missiles could also be aimed at targets within $1,000 \mathrm{~km}$ of the East-West German border exactly as if they were SS20s or Pershing IIs. The same difficulty has arisen previously, and it is now said that the British and French forces are tacitly allowed for in the Salt II treaty by means of the less stringent numerical limits with which Soviet missile forces must comply. What seems not to have been appreciated, during the long months at Geneva, is that the SS20 missiles are in some respects exactly comparable with the British and French nuclear forces. Although apparently designed for use against military targets such as troop concentrations, there is nothing to prevent their use against cities in Western Europe (and, because they are mobile, in the Far East). So the SS20s are both squarely within the ambit of INF and, because they supplement other Soviet strategic forces, also part of the START negotiations. The declaration by the North Atlantic Treaty Organization (NATO) in December 1979 that the appearance of SS20s within range of Western Europe would be met by the installation of Pershing II and cruise missiles could well have gone further and have protested that the appearance of the SS20s on the European scene was a breach of the Salt II agreement.

\section{Pitfalls}

The only moral in this sorry tale is that nuclear arms control is indivisible. If the two superpowers agree about some narrow aspect of the problem, the consequence will be a tendency for nuclear arms to pop up in greater numbers elsewhere, as they have now done in Europe, East and West. The case for separate talks at Geneva (while they lasted) was that the hope of winning agreement must be greater on a more restricted front. What should now be recognized is that such ambitions are certain to be fruitless. Whichever side is to blame for what has happened, there is everything to be said for mounting the next set of talks in a wider framework that will take account of unambiguously strategic superpower missiles as well as those held by the British and the French and otherwise sited in Europe.

But of what value is this conclusion if the two nuclear superpowers will not talk to each other? Fortunately, the hard work that needs to be done against this $\iota$ me next year does not require that there should be formal negotiations under way at some central location on neutral ground. The standard form on those occasions, anyway, is that people meet for a couple of hours twice a week. No purpose other than symbolic would be served by engaging senior public servants in a continuation of this charade until there is something for them to get their teeth into. A general understanding in Western Europe and North America that the nuclear problem is all of a piece would be a good beginning, and need not wait for the US presidential election in November. There is even, of course, a possibility that a different basis for some future set of talks might simplify the task of persuading the Soviet Union to talk again about the need for an agreement. Since the prospect of an agreement on a comprehensive test-ban, never bright, will be slim at least until the future of major missile systems in the United States has been decided, this is the best hope that the superpowers have of avoiding another drubbing in 1985. Is it really necessary to wait another year before waking up to what will then seem an urgent truth? 